\title{
HONOR JUDGE RICHARD F. MITCHELL
}

The Washington, D. C. Chapter of Interstate Commerce Commission Practitioners, held one of its most successful and best attended bi-monthly meetings on February 25 when Commissioner Richard F. Mitchell, of Ft. Dodge, Iowa, who succeeded the late Claude R. Porter, was the honored guest and speaker. All I. C. C. commissioners who were in the city on that date were present to honor their colleague who assumed his new duties on February 10. The large gathering which welcomed Commissioner Mitchell was representativie of practically every line of transportation and traffic activity.

The luncheon program was conducted by Edward F. Lacey, chairman of the Washington chapter. Judge Mitchell was introduced to the assemblage by I. C. C. Chairman Clyde B. Aitchison, who just 40 years to the day qualified as a member of the Oregon state commission. He gave an interesting discourse on the part that the state of Iowa has played in the history of the Interstate Commerce act. The state of Iowa has been represented on the commission since its inception except for very brief periods. Chairman Aitchison was born in Iowa, but later moved to Oregon.

Judge Mitchell gave a brief, impromptu talk, in which he spoke of his experiences as chief justice of the supreme court of Iowa, and his belief in rendering decisions promptly. He asserted that he is greatly interested in the activities of the ICC, and is anticipating his new duties with great enthusiasm. He also mentioned his housing difficulties since arriving in Washington, but finally had found temporary quarters for him and his family, consisting of his wife and two daughters.

Following Commissioner Mitchell's talk, the group present arose and gave him a warm welcome of applause and appreciation.-Interstate Commerce Commissioners' Journal. 
Copyright of Annals of Iowa is the property of State of Iowa, by \& through the State Historical Society of Iowa and its content may not be copied or emailed to multiple sites or posted to a listserv without the copyright holder's express written permission. However, users may print, download, or email articles for individual use. 